\title{
Using Wood-Shred, Rice-Straw and Brush-Wood-Dams with Planting Seedlings to Runoff and Erosion Control in a Forest Road Fill Slope
}

\author{
Mohammad Ali Fakhari, Majid Lotfalian, Seyed Ataollah Hosseini, \\ Abdulvahed Khaledi Darvishan
}

\begin{abstract}
This study aimed to investigate the effects of two types of natural geotextiles, including wood shred (WS), rice straw (RS) and the biomechanics method of brush wood dam (BWD) with planting seedlings of Alnus glutinosa and Salix alba on runoff, soil loss and fill slope. The effects were compared with those obtained from control treatment. A total of 36 plots $(2 \times 4 \mathrm{~m})$ with three replicates in the direction of gradient to fill slope of a forest road in northern Iran was considered. Soil moisture, canopy cover of seedlings, vegetation coverage, runoff, sedimentation and erosion were measured in plots during 12 months. BWD and WS played an effective role in reducing runoff by $57 \%$ and $73 \%$, respectively. By using RS and WS, the sediment concentration was decreased by $23 \%$ and $11 \%$, respectively, while by using BWD it increased by $58 \%$. RS $(24.16 \%)$ and BWD $(7 \%)$ had the greatest and smallest impact on reducing vegetation coverage, respectively. BWD (33\%) and RS $(27 \%)$ had the highest and lowest canopy cover of seedlings, respectively. Results showed that both RS (22.23\%) and A. glutinosa $(4.96 \%)$ had the greatest effects on increasing soil moisture. Comparison between the planted species and the control treatment (with no seedlings) showed that S. alba was effective in reducing runoff (46.22\%), while A. glutinosa was effective in reducing erosion $(66.89 \%)$ and sediment concentration (53.52\%). Finally, interactions between conservation treatment and planting of seedlings played a more effective role in controlling runoff and erosion. Therefore, the application of conservation treatments together with planting of seedlings is recommended in order to provide better soil conservation and restoration of fill slope.
\end{abstract}

Keywords: bioengineering, bio-mechanic, natural geotextiles, soil conservation, surface slip

\section{Introduction}

Forest roads are essential for various activities, including forest resource management, recreation, pests, diseases and fire control (Fedkiw 1998, Negishi et al. 2004, Avon et al. 2010); however, the construction and use of forest roads cause damage to the vegetation in the construction site making the field prone to erosion (Binkley and Brown 1993, Grace 2002). Studies have shown that forest roads are the main origin of sediment transport in rivers in forest areas (Cole and Landres 1996, Elliot et al. 2009).
Basic measures to reduce environmental damage to roads begin with the design and networking step (Lotfalian et al. 2013). Therefore, in designing forest roads, not only the costs should be considered but also the proper management of water and soil. A significant amount of runoff and sediment is observed in Hyrcanian forests because of the fine-textured soil (Lotfalian et al. 2019) and there are areas on fill slopes that are susceptible to erosion and prone to landslides despite the principles of road construction and technical buildings. Shallow slides are created in different sizes and shapes while using the road. Some of these 
surface slides, especially in areas with a low slope and a small area, are naturally stabilized and restored over time (because of easear stabilization), but larger areas or mountainous areas will be stabilized and restored later, or not only will they not be stabilized, but the extent of destruction area will also increase over time. The prolongation of the time of stabilization and restoration or expansion of the destruction area can increase the costs of maintenance and repair of forest roads, while creating environmental hazards. Therefore, in such areas, basic measures should be taken to stabilize fill slopes of the forest roads. Currently, various techniques are used to protect, sustain and repair damaged sloping areas. There are biotechnological methods for the growth and development of plants because of their environmental compatibility and economic benefits (low cost) compared to other methods (Albaladejo Montoro et al. 2000). Vegetation is more effective in soil and slope conservation when the canopy is closed and developed, because they are able to reduce the amount of runoff and soil erosion via interception and can reduce the amount of surface water and increase the soil stability through the root system (Coppin and Richards 1990, Sanchez and Puigdefabregas 1994, Álvarez-Mozos et al. 2014). In fact, the critical phase is between plant germination (planting) and full plant maturation, increasing the possibility of erosion (Rickson 2006) because seeds and seedlings during growth may be damaged or washed by a large amount of runoff. In this case, the vegetation establishment would be very difficult (Beikircheret al. 2010).

In this study, in order to prevent surface landslides and reduce erosion during early stages of plant growth, the mulching method (geotextile) was used by considering its potential for creating favorable conditions for plant growth and seedlings establishment by protecting the soil and seeds against the effects of rain damage (Brofas and Varelides 2000) as well as the biomechanical method (brush wood dams). Geotextiles are permeable materials used as a supplement to some projects in conjunction with soil, rock, or any geotechnical engineering related material (John 1987). In general, geotextiles are divided into two main categories:

\section{$\Rightarrow$ the original woven structure \\ $\Rightarrow$ the original non-woven structure.}

They are made of synthetic fibers (e.g., polypropylene, polyethylene, polyamide, etc.) or natural fibers (e.g., hemp, coconut fiber, wood chips, rice straw, palm leaves, etc.). In different designs, they are made in terms of size and shape according to their functions and requirements (Rickson 2006). Geotextiles with the original non-woven structures have better filtering properties due to their large volume and a relatively high empty space.

The construction of a dam is another common engineering solution against erosion and sediment control. Depending on the environmental conditions and costs, dams can be constructed in two general forms - temporary or permanent. Temporary dams are made of cheap local materials, such as tree branches, wood, stone, soil and other materials. (Sastry and Narayana 1984, Venkatesh et al. 2014). Wattle dams are one of this type used when the length of the erosion slope is less than $100 \mathrm{~m}$ and the area of the upstream region is less than one hectare. Assessment of biomedical methods is necessary to achieve the best available method with the least environmental risk and cost. Studies showed that erosion control and soil conservation with biological and non-biological methods on different slopes and rainfall intensities in both scales of plots and slopes using natural and simulated rainfalls had reduced the amount of sediment, runoff volume, helped the vegetation establishment and improved conditions for plant growth in damaged areas with difficult conditions (Gholami et al. 2016). Among them, natural geotextiles proved to be better than other materials and more effective for soil conservation and erosion control on steep slopes along the roads.

Few studies used natural rainfalls for applying biological soil protectors for protecting excavation and fill slopes of forest roads without evaluation of their efficiency and comparison with other engineering methods. Jourgholami and Abari (2017) evaluated the efficacy of straw and sawdust mulches in reducing soil erosion in a severely compacted loam soil area on a skid trail in the Hyrcanian forest. Therefore, the aim of this study was to evaluate three conservation treatments, including two types of natural non-woven geotextiles (mulches) (such as rice straw and wood shred) and brush wood dam (biomechanical method) by planting two native tree species (Alnus glutinosa and Salix alba) in order to reduce soil water erosion and protect fill slope of forest roads according to its dependent factors.

\section{Materials and methods}

\subsection{Study Site}

The study was conducted on a slippery and eroded fill slope of a forest road without tree, shrub and woody vegetation in Chamestan, North of Iran. The site is located on the northern slope with the longitude of $52^{\circ} 00^{\prime} 16^{\prime \prime}$ and latitude of $36^{\circ} 29^{\prime} 29^{\prime \prime}$ and an altitude of 160-150 m above sea level, with a mean slope of 

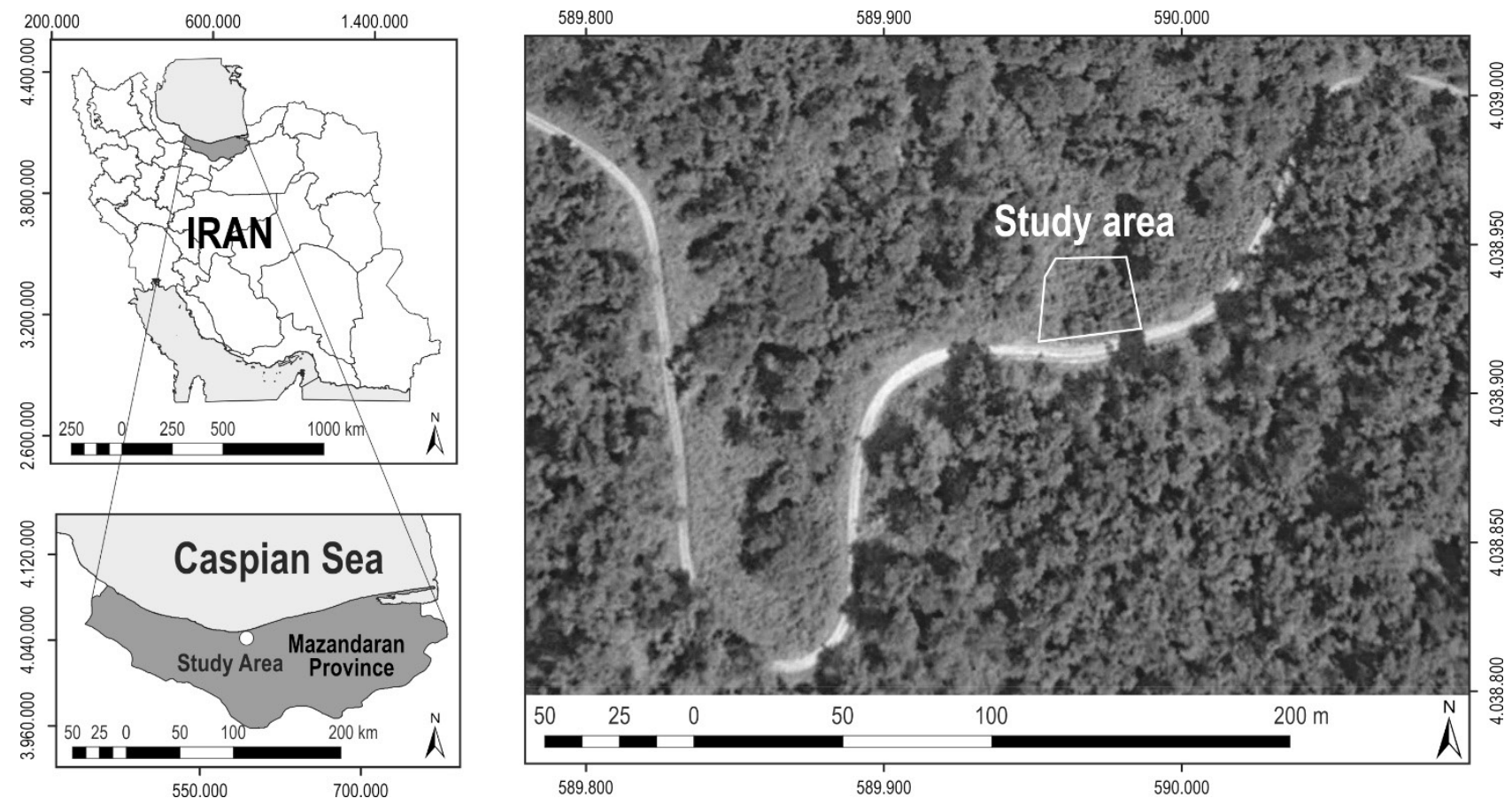

Fig. 1 Location of study area (after 1 year treatment)

$60 \%$. The experimental design was set up on an area $24 \mathrm{~m}$ wide, $18 \mathrm{~m}$ long, and an area of $432 \mathrm{~m}^{2}$ (Fig. 1).

According to the 30-year statistics (1964-1994) of Chamestan station, the mean annual temperature is $15.1^{\circ} \mathrm{C}$, the average annual rainfall is $799 \mathrm{~mm}_{\text {year }}{ }^{-1}$, and the highest and lowest monthly rainfall events (October and June) are 120 and $39 \mathrm{~mm}$, respectively. The dry period is from mid June to late August. According to the Emberger climate classification, the climate of the area is moderate and humid. Forest type is Quercus castaneifolia, Carpinus betulus and Zelkova carpinifolia. The soil type is forest brown soil with acidic $\mathrm{pH}$, heavy texture (clay), more than $1 \mathrm{~m}$ deep, fine granular to prismatic structure (fine-grained), depth of rooting up to $85 \mathrm{~cm}$, poor soil permeability and high sensitivity to erosion. Parent material is often lime, limestone and sandstone with little marl and low permeability (Asadpour and Habibi 2015).

The soil surface has a number of holes and lumps. It is very sticky and turns into a plastic form during
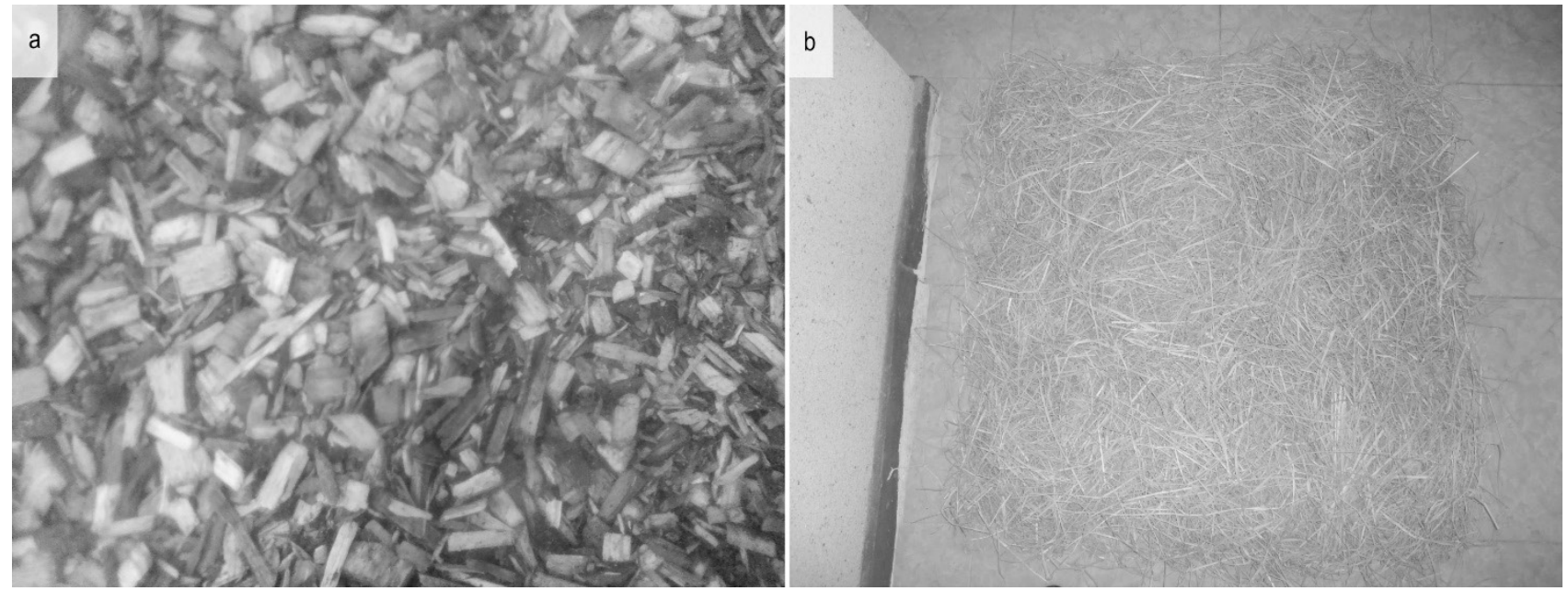

Fig. 2 Wood shred (a) and rice straw (b) used in plots 
rainfall and splits and gets hard during drought. Although 26 years have passed since the construction of the road, high runoff amount, low permeability, humidity fluctuations during rainfall and dry months and appearance of surface cracks in the dry seasons had caused soil erosion, road degradation, as well as the lack of seed and vegetation on the slopes and slides.

\subsection{Experimental Design}

In this study, after preparing the ground, three conservation treatments (main treatments) were used, including two types of non-woven natural geotextiles (mulches), such as rice straw and wood shred (Fig. 2), brush wood dam (biomechanical treatment) and control treatment together with planting one-year-old seedlings of two forest species of Alnus glutinosa and Salix alba (sub-treatment) with four completely randomized blocks and similarly used at a surface of about $72 \mathrm{~m}^{2}(12 \times 6 \mathrm{~m})$. Each block was divided into three rows (replicate) from the road edge down the slope and in the direction of the slope and each row was divided into three plots of $8 \mathrm{~m}^{2}(4 \times 2 \mathrm{~m})$ in the direction of contour lines. Therefore, each block contains 9 sub-plots of $8 \mathrm{~m}^{2}$, where alder seedlings were planted in each row (replicate) in one plot and in the next plot willow seedlings were planted with a density of 1 seedling $/ \mathrm{m}^{2}$. The remaining plots in each row were with no seedlings. Systematic random sampling was used for planting and arrangement of planting seedlings in plots based on species type. Therefore, in each block, three replicates were related to alder, three replicates were related to willow and three plots were with no seedlings and cover (control).The experimental design was a split plot. The first conservation treatment was rice straw (RS), which was non-woven material prepared from long fibers of rice. It was about $15 \mathrm{~mm}$ thick (compressed) with a weight of $700 \mathrm{~g} / \mathrm{m}^{2}$, which covered $100 \%$ of the soil surface. Another type of geotextile was wood shred (WS) provided by a wood factory. It was about $15 \mathrm{~mm}$ thick and its dry weight was about $2800 \mathrm{~g} / \mathrm{m}^{2}$, which covered $100 \%$ of the flat surface and $90 \%$ of the soil surface. Besides the two types of geotextiles, the next treatment was brush wood dam (BWD) made of $1.2 \mathrm{~m}$ long pillars prepared in four rounds. They were placed into the soil at a depth of $80 \mathrm{~cm}$ (according to the soil depth) and at a distance of $30 \mathrm{~cm}$ (6 in each plot) and then, the remaining $40 \mathrm{~cm}$ above the soil surface was covered in a zigzag shape using coppices and branches of iron tree. The last treatment was a control plot (CP), where no stabilization method was used (except planting) (Fig. 3).

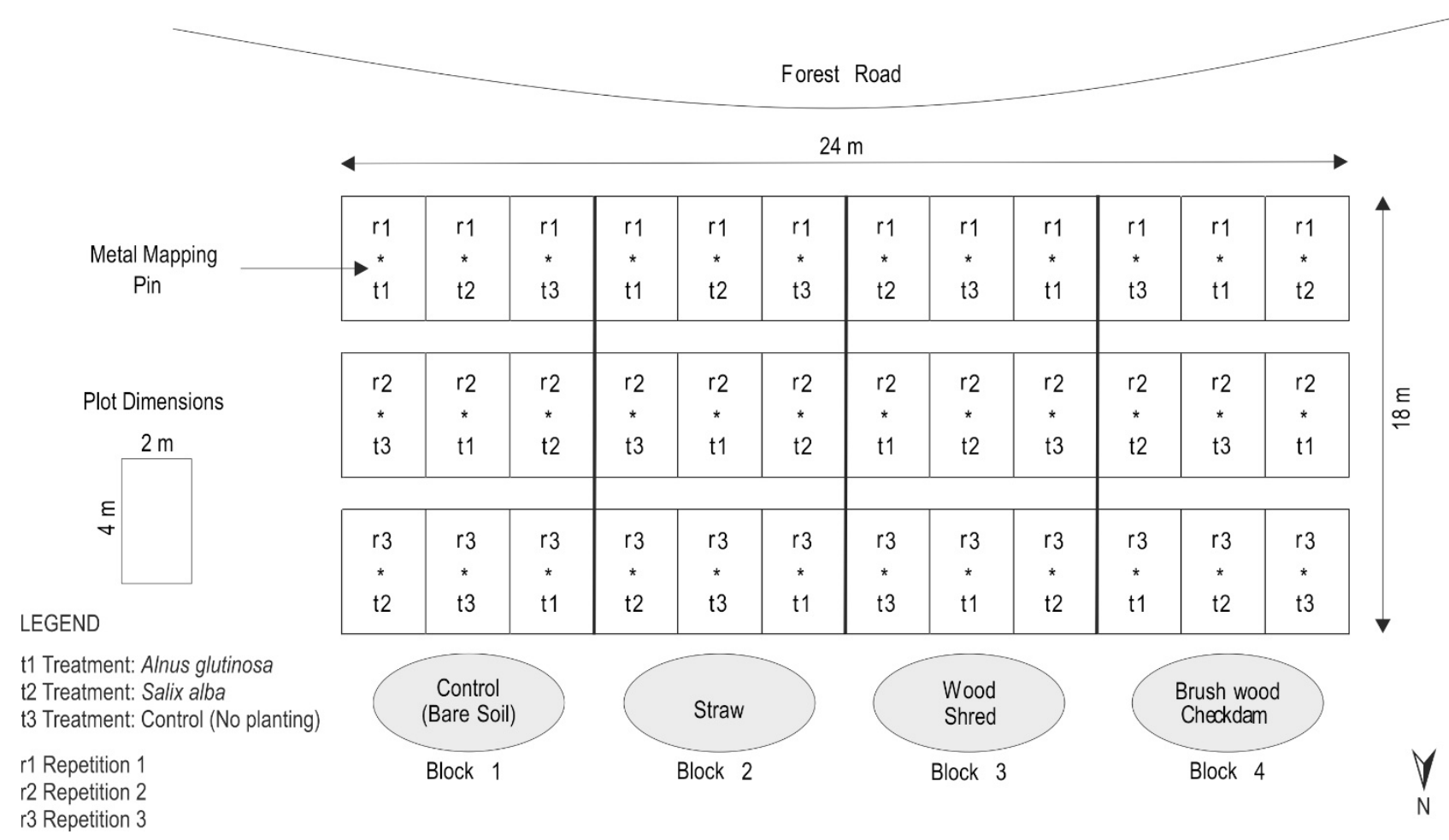

Fig. 3 An overview (experimental design) and blocks arrangement, plots and planted seedlings (experimental and control treatments) on the fillslope 
a) Partial view of the study-site before treatment setup

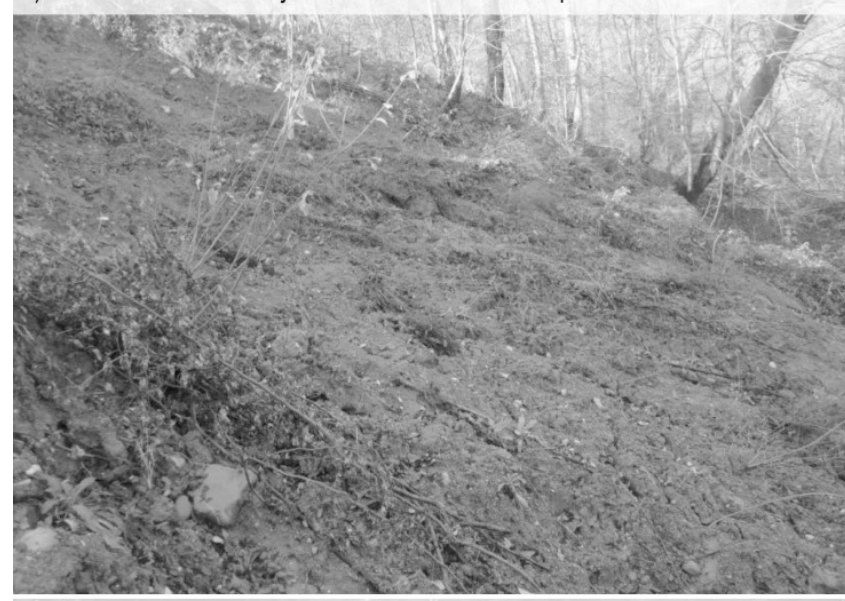

c) An overview of plots after setup

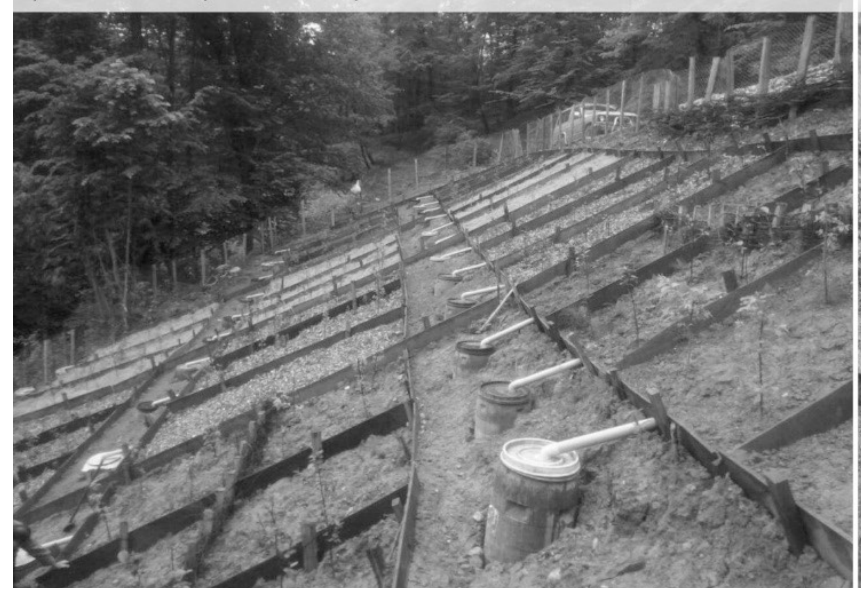

b) Preparing plots

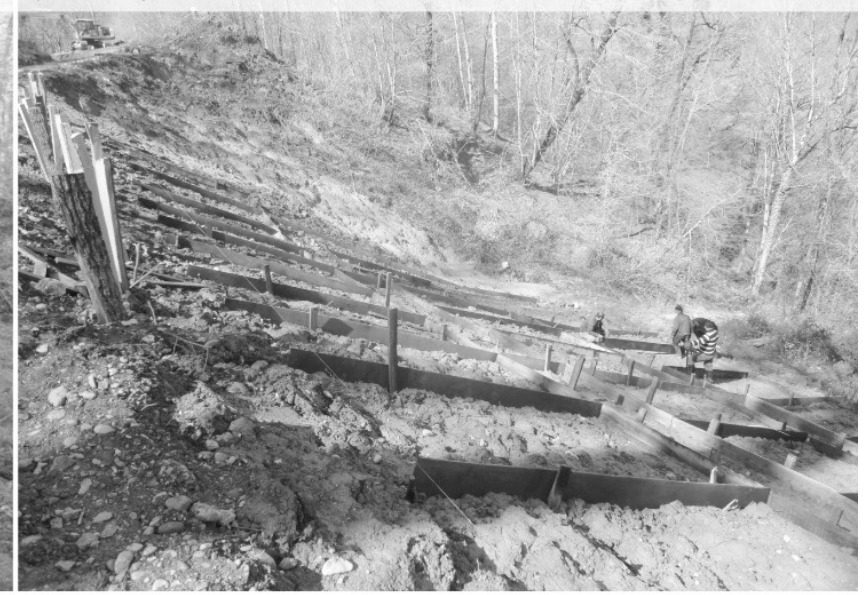

d) Plots one year after setup

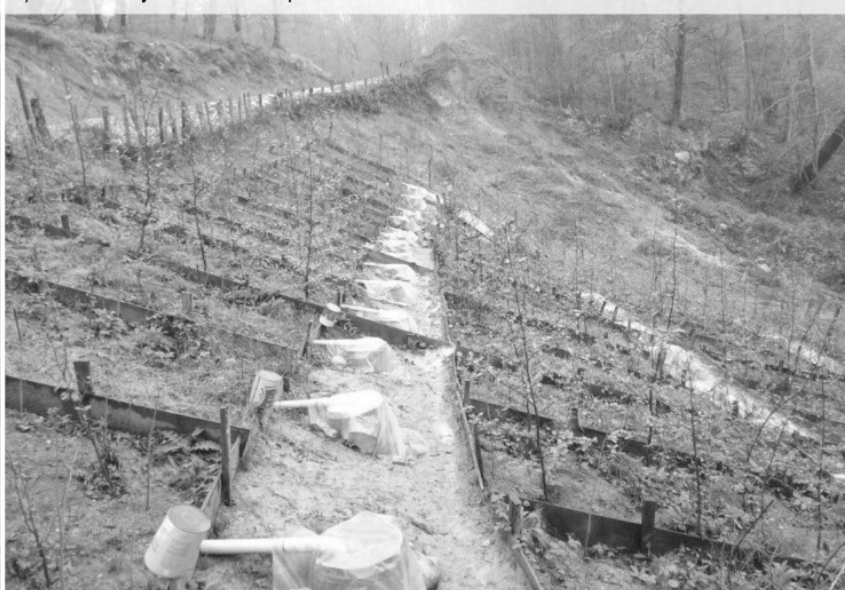

Fig. 4 Experimental setup

Rice straw and wood shred were selected due to their abundance, affordability and easy accessibility and alder due to being a native species, easy establishment, rapid growth, abundant rooting, high water consumption, soil improvement, naturally abundant presence in landslides, especially in soils of roadsides and abundant use in biological stabilization and biomedical methods. Besides the above mentioned species, willow was selected due to its abundance, easy and plentiful regeneration in reproductive and vegetative (cuttings) forms, failure to create the above ground biomass based on heavy woods, never reported as an attacker species (Anon. 1992). As shown in Fig. 3, the main plots (conservation treatments) and subplots (seedlings), were installed on the fill slopes of the forest road. The entire plots in one block were enclosed by boards to prevent water penetration and splash sediment to adjacent plots. After passing through a polyka pipe, runoff and sediment from the rainfall were transferred to a container (a 120 liter barrel). All blocks and plots had exactly the same conditions. The blocks were separated by type of treatments and plots were separated according to the type of planted species (Fig. 4).

\subsection{Measurement of Study Parameters}

From May $1^{\text {st }} 2015$ to May $1^{\text {st }} 2016$, after each rainfall event, a measurement team was immediately present at the site. The soil moisture content at a depth of $2 \mathrm{~cm}$ was recorded and monitored by a digital humidity meter in each plot. The total runoff volume was measured by a one-liter cylinder and a 4-liter container. In order to calculate the total amount of sediment, the method of decantation was used, then the sample was dried in the oven, and finally the results were generalized to the plot scale (Walling et al. 2001, Girmay et al. 2009). The sediment and water solution were transferred to the laboratory and deposited on the bottom of the bottle after 48 hours, the volume of filtered water at the upper part of the bottle was measured and 
then evacuated (Girmay et al. 2009). The remaining solution (water and sediment) was placed in an oven at $105^{\circ} \mathrm{C}$ for 24 hours. After water vaporization, the average mass of sediment in grams, the concentration of sediment in grams per liter and the total amount of sediment in grams were calculated by multiplying the sediment concentration in the total volume of runoff (Shao et al. 2014, Vega et al. 2015). Canopy percentage of planted seedlings and floor grass vegetation in each plot was also estimated based on species type and the observation method. During the observation period, the rainfall amount was measured by four rain gauges installed in the four experimental blocks.

\subsection{Data Analysis}

All data on 28 rainfall events were collected for a full calendar year. Then, analysis of variance (ANOVA) was used for determining soil moisture percentage, canopy percentage of planted seedlings, percentage of grass vegetation, runoff volume $(\mathrm{L})$, sediment concentration $(\mathrm{g} / \mathrm{L})$ and the total amount of produced sediment $(\mathrm{g})$ in experimental plots and for four treatments under planting conditions of two forest species (all plots), while Fisher's Least Significant Difference (LSD) was used for determining the multiple comparisons of the means to a significant level of $95 \%$ in Excel (version 2013) and SPSS (version 18) software. The effects of geotextiles (mulch), biomechanics (BWD), division and difference between observations of experimental treatments and control treatment and their comparison with block control were calculated and the results were as follows.

\section{Results}

\subsection{Variables Related to Rain Events}

From May $1^{\text {st }} 2015$ to May $1^{\text {st }} 2016$ (one year), 28 rainfall events with a total rainfall of $1087.71 \mathrm{~mm}$ were measured and recorded. The rate and distribution of rainfall were different during the study period, so that

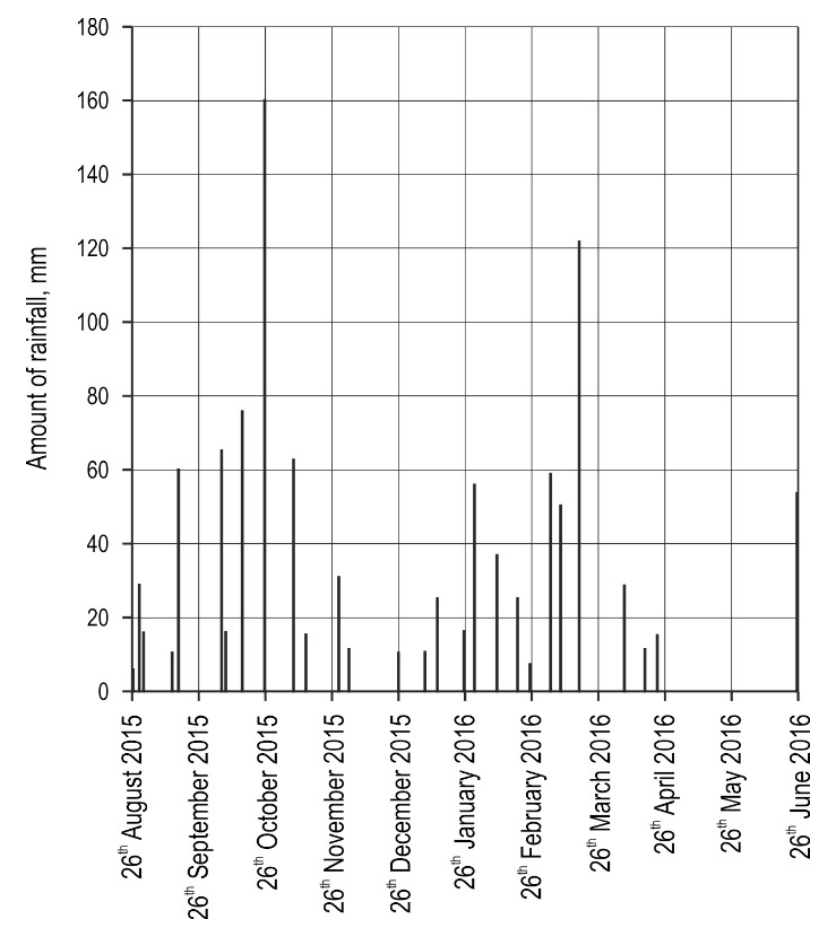

Fig. 5 Rainfall events from May 2015 to May 2016 in study area

the average annual rainfall was 38.85 , and the highest and lowest rainfall was 160.03 and $6 \mathrm{~mm}$, respectively (Fig. 5).

\subsection{Effects of Conservation Treatments and Seedling Planting}

Results of measurements of runoff, erosion, sediment concentration, moisture content at a depth $2 \mathrm{~cm}$ as well as changes in grass vegetation and canopy in different treatments are presented in Fig. 6. Conservation treatments and planting seedlings separately and their interactions compared to the control treatment on measured variables of runoff and erosion show different effects and are presented in Tables 1, 2 and 3, respectively.

Table 1 Effect of conservation treatments on study variables using multivariate analysis of variance

\begin{tabular}{|l|c|c|c|c|c|c|c|}
\hline \multicolumn{1}{|c|}{$\begin{array}{c}\text { Seedling planting } \\
\text { treatments }\end{array}$} & $\begin{array}{c}\text { Number of } \\
\text { Samples }\end{array}$ & Runoff & Sediment & $\begin{array}{c}\text { Sediment } \\
\text { concentration }\end{array}$ & Soil moisture & Canopy cover & $\begin{array}{c}\text { Vegetation } \\
\text { coverage }\end{array}$ \\
\hline & & $\mathrm{L}$ & $\mathrm{g}$ & $\mathrm{g} / \mathrm{L}$ & $\%$ & $\%$ & $\%$ \\
\hline Wood shred & 252 & 3.215 & 1.7 & 1.4 & 10.7 & 30 & 37 \\
\hline Rice Straw & 252 & 6.361 & 2.7 & 1.2 & 11.5 & 27 & 36 \\
\hline Brush wood dams & 252 & 3.003 & 2.8 & 2.5 & 9.8 & 33 & 44 \\
\hline Control & 252 & 6.990 & 6.4 & 1.6 & 9.4 & 48 & 27 \\
\hline Sig. & & 0.007 & 0.023 & 0.0000 & 0.000 & 0.000 & 0.000 \\
\hline
\end{tabular}



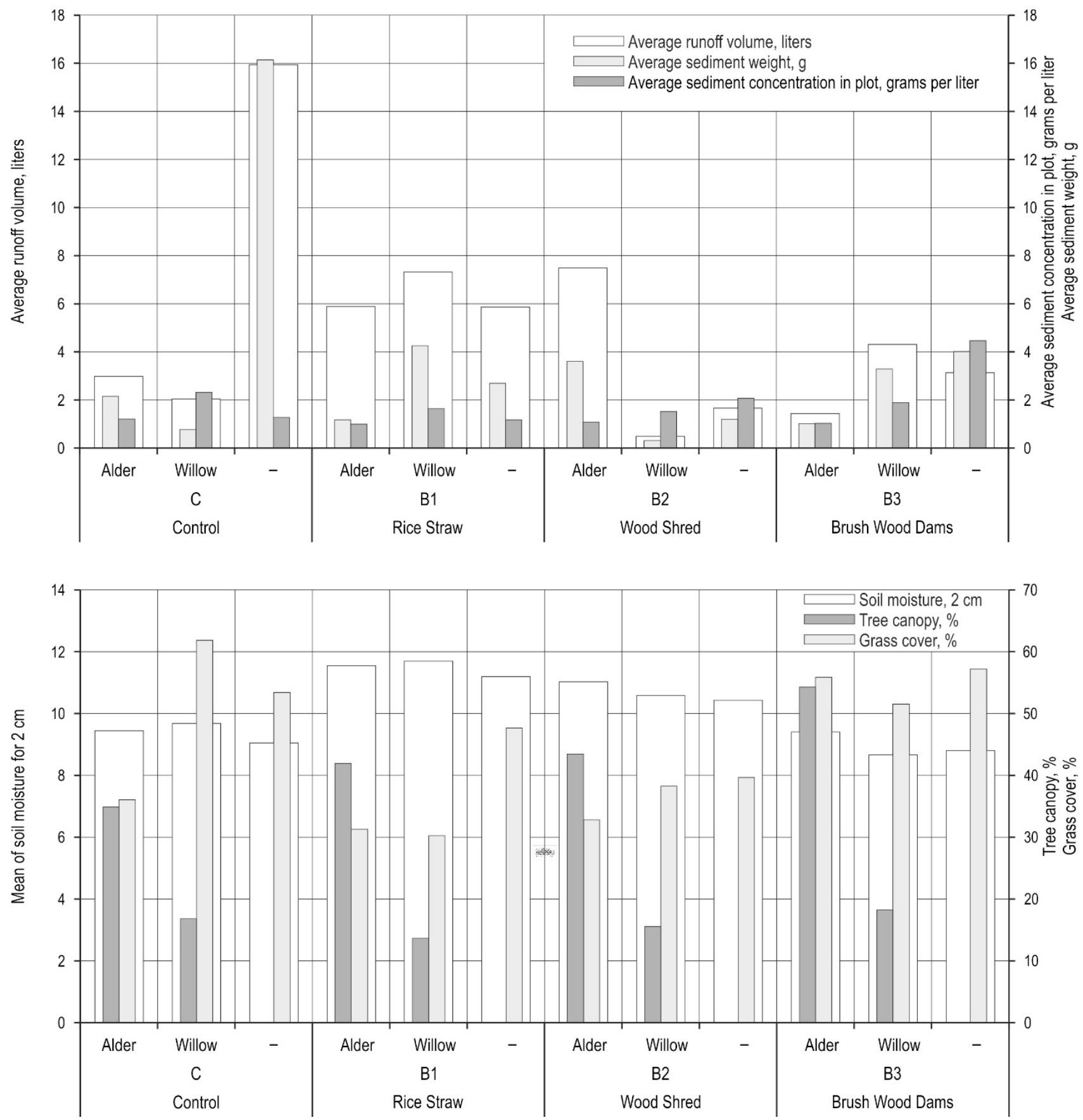

Fig. 6 Results of measurements of runoff and erosion, soil moisture, canopy and grass vegetation in different conservation treatments

The effects of interactions between conservation treatments and seedling planting in comparison with the control plot $(\mathrm{CP})$ on the studied variables are presented in Table 3.

The results of the field studies indicated that the control treatment had the highest runoff volume compared to the conservation treatments followed by straw and wood shred, while brush wood dams had the lowest runoff volume. The average volume of runoff for CP, RS, WS and BWD was measured as 6.990, $6.361,3.215,3.003$ liters, respectively.

In the overall comparison, the difference between the conservation treatments and $\mathrm{CP}$ was statistically significant $(p \leq 0.05)$; however, there was no significant difference between the RS and CP. In addition, no statistically significant difference was found between WS 
Table 2 Effect of seedling planting on study variables using multivariate analysis of variance

\begin{tabular}{|c|c|c|c|c|c|c|c|}
\hline \multirow{2}{*}{$\begin{array}{l}\text { Seedling planting } \\
\text { treatments }\end{array}$} & \multirow{2}{*}{$\begin{array}{l}\text { Number of } \\
\text { Samples }\end{array}$} & Runoff & Sediment & $\begin{array}{c}\text { Sediment } \\
\text { concentration }\end{array}$ & Soil moisture & Canopy cover & $\begin{array}{c}\text { Vegetation } \\
\text { coverage }\end{array}$ \\
\hline & & L & g & $\mathrm{g} / \mathrm{L}$ & $\%$ & $\%$ & $\%$ \\
\hline Willow & 336 & 3.577 & 2.2 & 1.8 & 10.2 & 16 & 46 \\
\hline Alder & 336 & 4.449 & 2.0 & 1.0 & 10.4 & 44 & 39 \\
\hline With no seedlings & 336 & 6.651 & 6.0 & 2.1 & 9.9 & - & 49 \\
\hline Sig. & & 0.042 & 0.005 & 0.000 & 0.025 & 0.000 & 0.000 \\
\hline
\end{tabular}

and BWD. The results of the sediment concentration were slightly different. In other words, sediment concentration in the BWD was more than that in $\mathrm{CP}$, but geotextiles (RS and WS) reduced the sediment concentration $(p \leq 0.01)$. The mean sediment concentrations for RS, WS, CP and BWD were measured as 1.18, 1.37, $1.55,2.45 \mathrm{~g} / \mathrm{L}$, respectively (Table 1 ).

The results of erosion control among the treatments showed (Table 1) that the CP had the highest sediment, followed by BWD and RS, and finally the least sediment was obtained in WS; hence, conservation treatments had a significant impact on decreasing sediment and soil losses $(p \leq 0.05)$. There was no sig- nificant difference between conservation treatments, but WS had the highest impact on decreasing sediment and soil losses. The average sediment content for WS, RS, BWD and CP was measured as 1.71, 2.71, 2.82, $6.35 \mathrm{~g}$, respectively (Table 2).

As shown in Table 3, the results of planting seedlings demonstrated that the planted species reduced the runoff volume and sediment mass compared to the plots with no seedlings, and their effects were significant $(p \leq 0.05)$. However, according to multiple comparisons, there was no significant difference between alder and CP (no-seedling plot). The average runoff in plots of willow, alder and with no seedlings was mea-

Table 3 Interactions of conservation treatments and seedling planting depending on study variables

\begin{tabular}{|c|c|c|c|c|c|c|c|}
\hline \multirow[t]{2}{*}{ Interactions } & \multirow{2}{*}{$\begin{array}{l}\text { Number of } \\
\text { Samples }\end{array}$} & Runoff & Sediment & $\begin{array}{c}\text { Sediment } \\
\text { concentration }\end{array}$ & Soil moisture & Canopy cover & $\begin{array}{c}\text { Vegetation } \\
\text { coverage }\end{array}$ \\
\hline & & $\mathrm{L}$ & g & $\mathrm{L} / \mathrm{g}$ & $\%$ & $\%$ & $\%$ \\
\hline Wood shreds and willow & 84 & 0.490 & 0.3 & 1.5 & 10.6 & 16 & 38 \\
\hline Wood shred and alnus & 84 & 7.492 & 3.6 & 1.1 & 11 & 44 & 33 \\
\hline Wood shred with no seedlings & 84 & 1.662 & 1.2 & 2.1 & 10.4 & - & 40 \\
\hline Rice Straw and willow & 84 & 7.332 & 4.3 & 1.7 & 11.7 & 14 & 30 \\
\hline Rice Straw and alder & 84 & 5.83 & 1.2 & 1.0 & 11.6 & 42 & 31 \\
\hline Rice with no seedlings & 84 & 5.862 & 2.7 & 1.1 & 11.2 & - & 48 \\
\hline Brush wood dams and willow & 84 & 4.37 & 3.3 & 1.9 & 8.7 & 18 & 52 \\
\hline Brush wood dams and alder & 84 & 1.430 & 1.0 & 1.0 & 9.4 & 54 & 56 \\
\hline $\begin{array}{l}\text { Brush wood dams with no } \\
\text { seedlings }\end{array}$ & 84 & 3.136 & 4.0 & 4.5 & 8.8 & - & 57 \\
\hline Control and willow & 84 & 2.044 & 0.8 & 2.3 & 9.7 & 17 & 62 \\
\hline Control and alder & 84 & 2.984 & 2.2 & 1.2 & 9.4 & 35 & 36 \\
\hline Control with no seedlings & 84 & 15.946 & 16.10 & 1.3 & 9.1 & - & 53 \\
\hline Sig. & & 0.000 & 0.000 & 0.000 & 0.484 & 0.000 & 0.000 \\
\hline
\end{tabular}


sured as 3.577, 4.449, 6.651 liter, respectively. The average sediment content in plots of alder, willow and with no seedlings was measured as 1.99, 2.19 and $6.01 \mathrm{~g}$, respectively. Furthermore, the results indicated that sediment concentration in plots with seedlings showed a significant difference in seedling plots $(p \leq 0.01)$. The average sediment concentrations in plots of alder, willow and with no seedlings were $0.99,1.80$ and $2.13 \mathrm{~g} / \mathrm{L}$.

The results of interception and soil moisture content in experimental plots during the measurement period and in relation to the rainfall intensity showed that the trend of soil moisture changes were similar in all treatments, while the values of soil moisture were different. Soil moisture content at a $2 \mathrm{~cm}$ soil depth in plots of RS, WS, BWD and CP was as 11.49, 10.68, 9.84, and $9.40(\%)$, respectively; therefore, it was significant compared to CP $(p \leq 0.01)$. The trend of soil moisture changes in relation to rainfall intensity showed that for seedling plots, the moisture content at a $2 \mathrm{~cm}$ soil depth in plots of alder, willow and with no seedlings (control) was equal to $10.36 \%, 10.16 \%$ and $9.87 \%$, respectively, but the difference was significant compared to $\mathrm{CP}(p \leq 0.05)$. However, there was no significant difference between alder and willow seedlings (Table 2).

The results of the observed estimation of the canopy cover percentage of planted seedlings and the percentage of grass vegetation of the floor after each rainfall event are shown in Table 1. The conservation treatments had significant effects on canopy cover and grass vegetation $(p \leq 0.01)$. The average percentages of canopy cover of seedlings in plots of BWD, WS, RS and $\mathrm{CP}$ were 33, 30, 27 and 27, respectively. The average percentage of grass vegetation of the floor for $\mathrm{CP}$, BWD, RS and WS was 48, 44, 37 and 36, respectively (Table 1). Moreover, significant differences were observed in the experiment plots between canopy cover of alder and willow $(p \leq 0.01)$. In other words, the average percentages of canopy cover for alder and willow were 44 and 16, respectively. Furthermore, the average grass vegetation in plots with no seedlings, alder and willow was $49,46 \%$, and $39 \%$, respectively. The difference between the grass vegetation percentages in plots with no seedlings and with seedlings was significant $(p \leq 0.01)$. In addition, there were significant differences in the percentages of grass vegetation between alder and willow plots $(p<0.05)$ (Table 2).

Interactions between conservation treatments and planting of seedlings on runoff volume, concentration and mass of sediment were significant compared to $\mathrm{CP}$ $(p \leq 0.01)$. The WS with willow had the lowest runoff $(0.49 \mathrm{~L})$ and the $\mathrm{CP}$ with no seedlings had the highest runoff $(15.95 \mathrm{~L})$. Furthermore, the results of sediment measurement showed that the WS with willow had the lowest sediment content $(0.32 \mathrm{~g})$ and the $\mathrm{CP}$ with no seedlings had the highest sediment content (16.14 g).

The lowest sediment concentration was related to RS with alder $(1.00 \mathrm{~g} / \mathrm{L})$ and the highest sediment concentration was related to BWD with no seedlings $(4.5 \mathrm{~g} / \mathrm{L})$. The interactions between conservation treatments and seedling planting on canopy percentage and grass vegetation percentage were also significant $(p \leq 0.01)$. However, it was not significant for the soil moisture content at $2 \mathrm{~cm}$ depth (Fig. 6).

\section{Discussion}

\subsection{Analyzing the Results of Runoff, Sediment Concentration and Sediment}

The results of field monitoring and surveys indicated that conservation treatments had the ability to absorb water and reduce water flow, and that the runoff volume in plots covered with geotextiles and BWD was significantly reduced. In other words, conservation treatments of $\mathrm{BWD}, \mathrm{WS}$ and $\mathrm{RS}$ reduced the runoff by $57.04 \%, 54.01 \%$ and $9.00 \%$, respectively. These result is consistent with Jourgholami and Abari (2017) who found that applying straw mulch to skid trail decreased the runoff by $36.5 \%$, while sawdust mulch decreased the runoff by $72.8 \%$ compared with the control.

Comparison of conservation treatments showed that, due to branches and leaves among the pillars, BWD prevented the water flow, which could consequently lead more water to penetrate the soil with the greatest effect in reducing the runoff. These results are consistent with those found by other researchers (Yanosek et al. 2006, Smets et al. 2007, Bhattacharyya et al. 2011, Foltz 2012, Han Luo et al. 2013, ÁlvarezMozos et al. 2014, Shao et al. 2014).

However, these results appear inconsistent with those of some previous studies in the forest (Davies et al. 2006, Gimenez-Morea 2010). These inconsistent results may be attributed to different geotextile materials used and soil characteristics. These studies considered geotextiles of palm leaves and cotton, which were hydrophobic and had low water permeability. WS, RS and BWD reduced erosion (sediment mass) by $73.07 \%$, $57.32 \%$ and $55.59 \%$, respectively. WS was shown to be more effective in reducing sediment because of solid and hard fibers. Similar to our results, the findings of a study conducted in western India showed that solid and hard fibers of coconuts (coir geotextile) reduced soil erosion by $99.63 \%$ during the pre-monsoon period and by $95.57 \%$ during the monsoon period. This can be attributed to protective buffering effect of geotextile, 
which absorbs the impact and kinetic energy of raindrops, and consequently can prevent erosion (Lekha 2004). In the semi-arid area in North China, hemp mat and polyester mat decreased the average erosion rate by $99.4 \%$ and $98.4 \%$, respectively, while the polyester network decreased it by $5.5 \%$ (Shao et al. 2014).

Lotfalian et al. (2019) investigated the effectiveness of three treatments of jute cover (JC), mulch cover $(\mathrm{MC})$ and bare cutslope as control plots $(\mathrm{CP})$ on cutslopes under the natural rainfall conditions. They found that the treatment of JC was superior. This treatment reduced the soil loss by 9.68 times compared to $\mathrm{CP}$ treatment. The effect of geotextile erosion control is very important, especially during the initial stages of repairing the slope in erosion areas as a temporary substitute for vegetation and stabilization, while the non-erosion environment has the opportunity to recover vegetation over time (Davies et al. 2006). Comparison of conservation treatments showed that RS had no significant effect on decreasing the runoff volume due to a string texture and abundant pores $(9.01 \%)$, however, it had a significant effect on the reduction of sediment mass (57.32\%) and ultimately the concentration of sediment (23.87\%). These results are consistent with those found by other researchers (Yanosek et al. 2006, Foltz 2012, Okeyoa et al. 2014). In other words, RS (23.87\%) and WS (11.61\%) reduced the sediment concentration, while BWD increased it (58.06\%). Comparison between planted seedlings and control treatments (with no seedlings) showed that although there was no significant difference between plots of alder and willow, willow seedlings played a more effective role in reducing the runoff volume. The reason could lie in the increase of the grass vegetation percentage and, consequently, greater influx of water into the soil. In other words, willow and alder seedlings reduced the runoff by $46.22 \%$ and $33.11 \%$, respectively. In contrast, alder seedlings had a better result in reducing the sediment mass and sediment concentration compared to the control and willow seedlings. In other words, alder and willow seedlings reduced the sediment concentration by $53.52 \%$ and $15.49 \%$, respectively. In addition, alder and willow seedlings reduced the sediment mass by $66.89 \%$ and $63.56 \%$ compared to plots with no seedlings. The reason was the difference in the percentage of canopy, which acted like a protective umbrella in reducing velocity and intensity of rain drops on the soil surface.

\subsection{Analyzing the Results of Moisture}

The results of soil moisture at a $2 \mathrm{~cm}$ depth in plots showed that natural geotextiles and BWD held greater soil moisture than $\mathrm{CP}$. They can hold the raindrops through reducing evaporation, increasing the permeability and water holding properties and increasing soil moisture and water productivity, and thus keep plants from drought stress in dry months of the year (two months in a year).This is particularly important in the maintenance and repair of the steep slopes (Balwinder et al. 2011, Li et al. 2013). Comparison between conservation treatments indicated that RS had a more effective role in maintaining moisture due to its high porosity and string texture, which acted like a sponge. In other words, RS, WS and BWD compared to $\mathrm{CP}$ increased soil moisture at a $2 \mathrm{~cm}$ depth by $22.23 \%, 13.62 \%$ and $4.68 \%$, respectively. These results are also confirmed by other studies. In one of these studies (Vishnudas et al. 2006) conducted in southern India, soil moisture was increased by $21 \%$. Another study (Lekha 2004) showed that soil moisture content in plots covered with palm leaves was $22 \%$ higher than that in control plots. Although alder and willow seedlings increased soil moisture content at a $2 \mathrm{~cm}$ depth by $4.96 \%$ and $2.94 \%$, respectively, their effects were less than those of conservation treatments and the reason lies in the interception and stem flow by seedlings.

\subsection{Analysis of the Results of Percentage of Seedlings Canopy and Grass Vegetation}

Compared to $\mathrm{CP}$, conservation treatments of BWD and WS increased the percentage of seedlings canopy by $22.22 \%$ and $11.11 \%$, respectively. However, RS had no significant effect. Increased seedlings canopy was due to the effects of geotextiles on reducing the nutrient losses and increased soil moisture content through reduced runoff and soil erosion. These results are in agreement with findings previously published by other researchers such as Cahill et al. (2005), Jankauskas et al. (2012), Bhattacharyya et al. (2013), Shao et al. (2014), Okeyoa et al. (2014). These studies showed that geotextiles reduced the runoff, sediment and eventually the nutrient loss.

Percentage of grass vegetation in treatment plots and planted plots was less than that in $\mathrm{CP}$ due to surface coating of the soil provided by conservation treatments and the shadow of seedlings canopy. Comparison between conservation treatments showed that RS, due to string texture and full coverage on the soil surface, and alder seedlings, due to a wider canopy than willow seedlings, were more effective in reducing the percentage of grass vegetation. In other words, RS, WS and BWD reduced the percentage of grass vegetation by $24.16 \%, 23.26 \%, 7 \%$, respectively and alder and willow seedlings reduced it by $21.20 \%$ and $8.03 \%$, respectively. In the assessment of the effects of three types of geotextiles of erosion control (hemp network, rough 
coconut fiber and three dimensional polyester geogrid) on the establishment and growth of plants on fillslopes of 45 and 60 degrees, Álvarez-Mozos et al. (2014) in the Public University of Navarre, Pamplona, Spain, showed that the initial plant establishment was 2 to 3 weeks faster in three dimensional polyester geogrid on both fill slopes compared to control (bare soil). However, rough coconut fiber significantly reduced the plant growth and vegetation cover on both fill slopes. The hemp network had contradictory results compared to control treatment, so that it increased the vegetation on a $45^{\circ}$ slope and reduced vegetation at a $60^{\circ}$ slope.

\section{Conclusion}

This study demonstrated the effects of geotextiles on the conservation of the forest road fill slopes. The results of natural rainfall observations showed that conservation treatments were effective in reducing the runoff volume, soil erosion, sediment concentration and in maintaining soil moisture by diminishing evaporation, and that they provided better conditions for seedlings growth. Among the conservation treatments, BWD showed better performance in reducing the runoff and growth of herbaceous plants. The WS had the highest impact on the reduction of the runoff volume and soil erosion, and the RS was more effective in reducing sediment concentration and evaporation (maintaining soil moisture). Comparison between two planted species indicated that alder seedlings were more effective in decreasing soil erosion and sediment concentration. Moreover, willow seedlings showed better performance in reducing the runoff volume and evaporation (maintaining soil moisture). Therefore, the use of RS and WS with planting seedlings had the best results in soil conservation and fill slope maintenance of forest roads. In contrast, the soil with no conservation treatment and seedlings (bare soil) had the worst results. So, it can be concluded that, for soil conservation, runoff prevention and maintenance of soil moisture for growing plants, all roadside fill slopes should be covered by geotextiles as soon as possible.

\section{References}

Albaladejo Montoro, J., Alvarez Rogel, J., Querejeta, J., Díaz, E., Castillo, V., 2000: Three hydro-seeding revegetation techniques for soil erosion control on anthropic steep slopes. Land Degradation \& Development 11(4): 315-325. https://doi. org/10.1002/1099-145X(200007/08)11:4<315::AIDLDR394>3.0.CO;2-4
Álvarez-Mozos, J., Abad, E., Giménez, R., Campo, M.A., Goñi, M., Arive, M., Casalí, J., Díez, J., Diego, I., 2014: Evaluation of erosion control geotextiles on steep slopes. Part 2: Influence on the establishment and growth of vegetation. CATENA 121: 195-203. https://doi.org/10.1016/j.catena.2014.05.015

Asadpour, F., Habibi, A., 2015: Strategies for climatic design for sustainable urban housing development (case study of Nur City, mazandaran, Iran). Cumhuriyet Science Journal 36(6): 653-664.

Avon, C., Bergès, L., Dumas, Y., Dupouey, J.L., 2010: Does the effect of forest roads extend a few meters or more into the adjacent forest? A study on understory plant diversity in managed oak stands. Forest Ecology and Management 259(8): 1546-1555. https://doi.org/10.1016/j.foreco.2010.01.031

Balwinder, S., Eberbach, P.L., Humphreys, E., Kukal, S.S., 2011: The effect of rice straw mulch on evapotranspiration, transpiration and soil evaporation of irrigated wheat in Punjab, India. Agricultural Water Management 98(12): 1847-1855. https://doi.org/10.1016/j.agwat.2011.07.002

Beikircher, B., Florineth, F., Mayr, S., 2010: Restoration of rocky slopes based on planted gabions and use of droughtpreconditioned woody species. Ecological Engineering 36(4): 421-426. https://doi.org/10.1016/j.ecoleng.2009.11.008

Bhattacharyya, R., Fullen, M.A., Booth, C.A., 2011: Using palm-mat geotextiles on an arable soil for water erosion control in the UK. Earth surface processes and landforms 36(7): 933-945. https://doi.org/10.1002/esp.2123

Bhattacharyya, R., Fullen, M.A., Booth, C.A., Black, A.W., Townrow, D., 2013: Using palm-mat geotextiles for soil conservation: II. Effects on in situ soil particle size distribution and nutrient concentration. Catena 101: 143-156. https://doi. org/10.1016/j.catena.2012.09.002

Binkley, D., Brown, T.C., 1993: Forest practices as nonpoint sources of pollution in North America. Journal of the American Water Resources Association 29(5): 729-740. https://doi. org/10.1111/j.1752-1688.1993.tb03233.x

Brofas, G., Varelides, C., 2000: Hydro-seeding and mulching for establishing vegetation on mining spoils in Greece. Land degradation \& development 11(4): 375-382. https://doi. org/10.1002/1099-145X(200007/08)11:4<375::AIDLDR400>3.0.CO;2-G

Cahill, A., Chalker-Scott, L., Ewing, K., 2005: Wood-chip mulch improves plant survival and establishment at no-maintenance restoration site (Washington). Ecological restoration 23: $212-213$.

Cole, D.N., Landres, P.B., 1996: Threats to wilderness ecosystems: impacts and research needs, Ecological Applications 6(1): 168-84. https://doi.org/10.2307/2269562

Coppin, N.J., Richards, I.G., 1990: Use of Vegetation in Civil Engineering. CIRIA, Butterworths, London, UK, ISBN086017-711-4, $52 \mathrm{p}$.

Davies, K., Fullen, M.A., Booth, C.A., 2006: A pilot project on the potential contribution of palm-mat geotextiles to soil con- 
servation. Earth Surface Processes and Landforms 31(5): 561-569. https://doi.org/10.1002/esp.1349

Elliot, W.J., Foltz, R.B., Robichaud, P.R., 2009: Recent findings related to measuring and modeling forest road erosion. In: Anderssen, RS; Braddock, RD; Newham, LTH, eds. $18^{\text {th }}$ World IMACS Congress and MODSIM09 International Congress on modelling and simulation; July 13-17, Cairns, Australia. Modelling and Simulation Society of Australia and New Zealand; and International Association for Mathematics and Computers in Simulation: 4078-4084.

Fedkiw, J., 1998: Managing multiple uses on national forests, 1905-1995: a 90-year learning experience and it isn't finished yet. USDA \& Forest Service, 308 p.

Foltz, R.B., 2012: A comparison of three erosion control mulches on decommissioned forest road corridors in the northern Rocky Mountains, United States. Journal of Soil and Water Conservation 67(6): 536-544. htpps://doi.org/10.2489/ jswc.67.6.536

Giménez-Morera, A., Sinoga, J.D.R., Cerdà, A., 2010: The impact of cotton geotextiles on soil and water losses from Mediterranean rainfed agricultural land. Land Degradation \& Development 21(2): 210-217. https://doi.org/10.1002/ldr.971

Girmay, G., Singh, B.R., Nyssen, J., Borrosen,T., 2009: Runoff and sediment associated nutrient losses under different land uses in Tigray, Northern Ethiopia. Journal of Hydrology 376(1-2): 70-80. https://doi.org/10.1016/j.jhydrol.2009.07.066

Gholami, L., Khaledi Darvishan, A., Kavian, A., 2016: Wood chips as soil conservation in field conditions. Arabian Journal of Geosciences 9(19): 729. https://doi.org/10.1007/s12517-0162731-0

Grace, J.M., 2002: Control of sediment export from the forest road prism. Transactions of the ASAE 45(4): 1127-1132.

Jankauskas, B., Jankauskienė, G., Fullen, M.A., 2012: Soil conservation on road embankments using palm-mat geotextiles: field studies in Lithuania. Soil Use and Management 28(2): 266-275. https://doi.org/10.1111/j.1475-2743.2012.00399.x

John, N.W.M., 1987: Geotextiles. Blackie and Son, Glasgow, New York, USA, ISBN:0216919959.

Jourgholami, M., Abari, M.E., 2017: Effectiveness of sawdust and straw mulching on postharvest runoff and soil erosion of a skid trail in a mixed forest. Ecological Engineering 109(A): 15-24. https://doi.org/10.1016/j.ecoleng.2017.09.009

Lekha, K.R., 2004: Field instrumentation and monitoring of soil erosion in coir geotextile stabilised slopes - a case study. Geotextiles and Geomembranes 22(5): 399-413. https://doi. org/10.1016/j.geotexmem.2003.12.003

Li, X.H., Zhang, Z.Y., Yang, J., Zhang, G.H., Wang, B., 2011: Effects of Bahia Grass Cover and Mulch on Runoff and Sediment Yield of Sloping Red Soil in Southern China. Pedosphere 21(2): 238-243. https://doi.org/10.1016/S1002-0160(11)60123-9

Lotfalian, M., Parsakhoo, A., Kavian, A., Hosseini, S.A., 2013: Runoff and sediment concentration of different parts of a road in Hyrcanian forests. Forest Science and Practice 15(2):144-151. https://doi.org/10.1007/s11632-013-0212-z

Lotfalian M., Babadi T.Y., Akbari H., 2019: Impacts of Soil stabilization treatments on reducing soil loss and runoff in cutslope of forest roads in Hyrcanian forests. CATENA 172: 158-162. https://doi.org/10.1016/j.catena.2018.08.023

Luo, H., Zhao, T., Dong, M., Gao, J., Peng, X., Guo, Y., Wang, Z., Liang, C., 2013: Field studies on the effects of three geotextiles on runoff and erosion of road slope in Beijing, China. CATENA 109:150-156. https://doi.org/10.1016/j.catena.2013.04.004

Negishi, J.N., Noguchi, S., Sidle, R.C., Abdul Rahim, N., 2004: Some observations on logging road recovery: implications to road rehabilitations. Proceedings of the international workshop on the landscape level rehabilitation of degraded tropical forests. Forestry and Forest Product Research Institute, Tsukuba, 12: 29-36.

Okeyoa, A.I., Mucheru-Munaa, M., Mugwea, J., Ngeticha, K.F., Mugendib, D.N., Dielsc, J., Shisanyaa, C.A., 2014: Effects of selected soil and water conservation technologies on nutrient losses and maize yields in the central highlands of Kenya. Agricultural Water Management 137: 52-58. https://doi. org/10.1016/j.agwat.2014.01.014

Rickson, R.J., 2006: Controlling sediment at source: an evaluation of erosion control geotextiles. Earth Surface Processes and Landforms: The Journal of the British Geomorphological Research Group 31(5): 550-560. https://doi.org/10.1002/ esp.1368

Sanchez, G., Puigdefabregas, J., 1994: Interactions of plant growth and sediment movement on slopes in a semi-arid environment. Geomorphology 9(3): 243-260. https://doi. org/10.1016/0169-555X(94)90066-3

Sastry, G., Narayana, V.V.D., 1984: Watershed Responses to Conservation Measures. Journal of Irrigation and Drainage Engineering 110(1): 14-20. https://doi.org/10.1061/ (ASCE)0733-9437(1984)110:1(14)

Shao, Q., Gu, W., Dai, Q.Y., Makoto, S., Liu, Y., 2014: Effectiveness of geotextile mulches for slope restoration in semi-arid northern China. CATENA 116: 1-9. https://doi.org/10.1016/j. catena.2013.12.006

Smets, T., Poesen, J., Fullen, M.A., Booth, C.A., 2007: Effectiveness of Palm and Simulated Geotextiles in Reducing Run-Off and Inter-Rill Erosion on Medium and Steep Slopes. Soil Use and Management 23(3): 306-316. https://doi. org/10.1111/j.1475-2743.2007.00098.x

Vega, J.A., Fernández, C., Fonturbel, T., 2015: Comparing the effectiveness of seeding and mulching+seeding in reducing soil erosion after a high severity fire in Galicia (NW Spain). Ecological Engineering 74: 206-212. https://doi.org/10.1016/j. ecoleng.2014.10.019

Venkatesh, B., Lakshman, N., Purandara, B.K., 2014: Hydrological impacts of afforestation - A review of research in India. Journal of Forestry Research 25(1): 37-42. https://doi. org/10.1007/s11676-014-0431-8 
Vishnudas, S., Savenije, H.H.G., Anil, K.R., Balan, K., 2006: The protective and attractive covering of a vegetated embankment using coir geotextiles. Hydrology and Earth System Sciences 10(4): 565-574.

Walling, D.E., Collins, A.L., Sichingabula, H.M., Leeks, G.J.L., 2001: Integrated assessment of catchment suspended sedi- ment budgets: a Zambian example. Land degradation \& development 12(5): 387-415. https://doi.org/10.1002/ldr.461

Yanosek, K.A., Foltz, R.B., Dooley, J.H., 2006: Performance assessment of wood strand erosion control materials among varying slopes, soil textures, and cover amounts. Journal of Soil and Water Conservation 61(2): 45-51.

(C) 2018 by the authors. Submitted for possible open access publication under the terms and conditions of the Creative Commons Attribution (CC BY) license (http://creativecommons.org/licenses/by/4.0/).

Received: February 08, 2018

Accepted: February 02, 2019
Authors' addresses:

Mohammad Ali Fakhari, PhD

e-mail: fakhari_r1378@yahoo.com

Prof. Majid Lotfalian, PhD *

e-mail: mlotfalian@sanru.ac.ir

Sari University of Agricultural Sciences

and Natural Resources

Faculty of Natural Resources

Department of Forestry

Sari

IRAN

Prof. Seyed Ataollah Hosseini, PhD

e-mail: at.hosseini@ut.ac.ir

University of Tehran

Faculty of Natural Resources

Department of Forestry and Forest Economics

Karaj

IRAN

Assist. prof. Abdulvahed Khaledi Darvishan, PhD

e-mail: a.khaledi@modares.ac.ir

Tarbiat Modares University

Department of Watershed Management

Noor 4641776489

IRAN

* Corresponding author 